\title{
Ulster's Protestant Working Class: A Community Exploration
}

\author{
Michael Hall, \\ with an introduction by \\ Billy Hutchinson
}

\section{INTRODUCTION}

In October 1992, the Springfield Inter-Community Development Project organised a conference for community groups working on both sides of the West Belfast 'peace-line' interface. Its purpose was to assist these groups to develop a joint strategy for tackling the common social and economic problems which beset them. However, this exploratory conference kept its agenda flexible, for it was realised that, before the two estranged communities could begin to co-operate on socio-economic issues, much fear and misunderstanding had to be confronted. The conference, therefore, allowed the delegates a chance not only to describe the problems they faced, but to voice the fears and suspicions held by their respective communities.

As the conference report clearly revealed, ${ }^{1}$ the depth of misunderstanding between the two communities was dramatically confirmed, with each 'side' revealing a confused and rudimentary appreciation of the fears and aspirations held by the other. It was also apparent that, even within each community, there was confusion and uncertainty, and the feeling that needs and aspirations had never been adequately articulated, let alone acknowledged.

The organisers decided that it would be worth while to assist each community in beginning such a process of articulation. As a first step, a series of meetings was held on the Shankill Road in the first half of 1994 which sought to explore the Protestant working-class experience. This essay is the product of those discussions.

The Springfield Inter-Community Development Project would hope to facilitate the same process within the Catholic working class. We believe such explorations are vital if we are ever to develop genuine inter-communal awareness, something still lacking after twenty-five years of unremitting violence. Only when our two communities face each other with honesty and openness, and with a preparedness to let dialogue replace violence, can we ever hope to transcend our present tragic circumstances.

This essay first appeared as a monograph under the same title published in 1994 by Island Publications, Newtownabbey, Co. Antrim, Northern Ireland, ISBN 189951000 1. It is reprinted here with the kind permission of the copyright holder. 


\section{A Cautionary Note}

A frequent complaint voiced by Northern Ireland's Protestant working class is that media and government continually view their community in a simplistic and stereotypical manner, with little attempt made to acknowledge the diversity of experiences and opinions. As our own discussions were, of the practical necessity, focused within that section of the Protestant working class living along Belfast's Shankill Road, we wondered whether we might fall into the same trap. For who could say whether opinions expressed along the Shankill Road necessarily reflect those of other Protestant working-class communities elsewhere throughout Northern Ireland?

Two things served to lessen our concerns. First, we acknowledged that, when the media and others use the phrase 'the Shankill and the Falls' as a synonym for the two working-class communities within Northern Ireland, it is not simply for the sake of a convenient label, but because it is believed that the hopes, fears, and aspirations of the people living along both those roads have indeed come to reflect closely the hopes, fears, and aspirations of Northern Ireland's two working-class communities in general.

Second, we endeavoured to make our discussions as broadly-based as possible, and invited along individuals whom we felt would reflect a wide cross-section of opinion within the Protestant working class. To further extend our outreach, those who attended the meetings were requested to share our deliberations with their own circle of contacts, and thereby stimulate additional feedback. The organisers feel reasonably confident, therefore, that the views we managed to canvas provide us with a broad overview of Protestant workingclass opinion - and the wide diversity of opinion expressed at the discussions gave ample proof of that.

The organisers express their gratitude to those who formed the core of the discussions, with a further thanks to all those who took the time to forward us written submissions. The quality of those discussions and the standard of the written submissions seem to indicate that the days of Protestant, working-class inarticulateness are at last hopefully numbered.

Cross-community worker and writer, Michael Hall, was invited to co-chair the discussions and to prepare the essay which now follows.

\section{ACKNOWLEDGING A CRISIS ...}

The initial belief that there was a pressing need for the series of discussions was very soon confirmed. The early opinions and comments expressed, both within the discussion group and outside of it, gave ample indication that the Protestant working class is presently undergoing a period of unprecedented transition, one which almost warrants the label of crisis.

This crisis has engendered many different reactions within the Protestant working-class community: a numbing sense of bewilderment, an increasing feeling of demoralisation, not to mention a deep resentment and bitterness. 
Amidst these disparate reactions, there are some common threads. There is the belief that, over the last twenty-five years, the Protestant working class has become increasingly isolated and marginalised. Its members feel that their deeply-held aspirations have rarely been acknowledged as legitimate by outsiders. Their 'case' has either been denigrated or ignored, or misrepresented by the media and government. Indeed, the media is felt to have been fixated with the cause of Irish Republicanism to the point of remaining oblivious to any suggestion that the heritage defended by Ulster's Protestant community could be every bit as valid.

The Protestant working class and its organisations are frequently viewed, and presented, as being largely composed of bigoted reactionaries, whose prime motivation is to prevent the Catholic community from gaining any advantage. Such a perception ignores the fact that some of the most progressive proposals to have emerged over recent years have come from Protestant working-class organisations. 2

Many feel that the suffering inflicted upon, and often deliberately directed against, the Protestant community by the IRA has never been fully acknowledged. Nor have the social and economic needs of the Protestant working class been adequately addressed.

Ironically, despite the high profile and vociferousness of many Unionist politicians, a frequent complaint from the Protestant working class is a feeling of being 'leaderless.' These politicians might be staunch in defence of the Union, but in the opinion of many working-class Protestants, they show little willingness to lead their constituents anywhere beyond 'Ulster Says No' and into a new future.

\section{THE CRISIS OF IDENTITY}

One of the most traumatic consequences of the past twenty-five years upon the Protestant working class has been its crisis of identity. Despite the intensity of IRA violence, the Republican onslaught has not been the main cause of this crisis - after all, the IRA was always considered a 'known' enemy, suspected by many Protestants of waiting in the wings, ready to seize any opportunity to renew its habitual assault upon the Northern Ireland state. Instead, it is the British government which has been primarily responsible for the deep trauma within the Protestant psyche, for its actions have engendered an increasing sense of betrayal, which twenty-five years on had led to the almost total estrangement of Protestant Ulster ${ }^{3}$ from 'mother' England. Most workingclass Loyalists now believe that their 'loyalty' counts for little on the mainland - Britain no longer wants them.

What exactly is it that Ulster Loyalists are 'loyal' to? And what is the identity so dearly held by Ulster's Protestants? Ironically, the assertion made by their detractors that this identity is at best a 'hybrid' one or at worst a false consciousness fabricated by the 'Brits,' often seems to be confirmed by the confusion and uncertainty acknowledged by Protestants themselves. 
We always loudly proclaimed that 'we are the people.' But just what 'people' are we - British, Irish, Northern Irish, Ulster-Costs? The young people I work with often only seem able to define themselves in opposition to others - they don't know fully what they are, but they know exactly what they're not! 4

Some place the blame for this situation on the education system:

Our schools never made any serious attempt to help us understand our real heritage. Apart from 1690 and 1921, what did we ever learn about this history of our own homeland? We got plenty of English history drummed into us - but next to nothing about Ulster.

Such 'avoidance' by the schools was to leave most Protestants ill-prepared to counter what they considered to be the biased version of Ulster's history invariably incorporated into every TV documentary on the 'Troubles.'

We knew full well that the media were short-changing us when it came to presenting 'our' side of the story, but what was our side of the story? We couldn't even explain it properly ourselves. And that's still the same. There's been plenty of times people around here have refused to take part in cross-community meetings, not because we don't want to sit down with Catholics, but because we don't have the self-confidence to do so. Few of us can articulate our case the way they can theirs.

'They' - the Catholic community - are often begrudgingly acknowledged to 'know their history inside out'.

Let's face it - the Republicans have really got their act together, especially their 'Irish heritage'. It has given them a sense of purpose which has sustained them through times of adversity. They've done a thorough job of it, so fair play to them, that's all I can say. But us? Oh no - we stumble from crisis to crisis, and even though we possess an equally legitimate heritage, at times it seems no bloody use to us. It's high time we got our act together.

In substance, the Ulster Protestant heritage is an amalgamation of certain diverse strands: religious affiliation, a 'British' consciousness, an almost 'ethnic' sense of group identification, a genuinely-held sense of 'belonging' to Ulster, and, for the working class, the reality of their social and economic circumstances. Yet none of these strands by itself necessarily explains why Ulster's Protestants should feel so 'different' from the rest of the island, and to some extent their sense of 'difference' has been partly reinforced because others also perceive them as 'different.' 
Religious affiliation need not necessarily have resulted in Protestantism being so seemingly incompatible to the concept of 'Irishness.' Indeed, Protestants have been at the forefront in the development of all things Irish, even the birth of Republicanism. Yet Daniel O'Connell, within five years of achieving Catholic Emancipation, stated that "Protestants were "foreigners" to us since they are of a different religion,' 5 and in more modern times, De Valera claimed that 'since the coming of Saint Patrick ... Ireland has been a Christian and a Catholic nation ... She remains a Catholic nation.' 6 Somehow, the Protestants of Ireland ceased to figure in the 'Irish' consciousness, and their contribution to this island's heritage was conveniently ignored.

Not that this has troubled many Protestants, for whom any such contribution made by their forefathers was an aberration, even traitorous.

I remember taking a group of Shankill Road teenagers to the old cemetery at the bottom of the Antrim Road, and I pointed out where the bones of Henry Joy McCracken are believed to have been interred. I told the young people that this was the grave of a famous Belfast Protestant hanged by the British. 'What had he done?' one asked, quite sympathetic in tone, for there was nothing unusual about Protestants finding themselves in conflict with the Crown. 'He was one of the founders of Irish Republicanism,' I replied. A look of complete disdain came over the teenager - 'Served the bastard right, then!'

Many Protestants would feel in full accord with such 'disdain.'

The Unionist Loyalist population have no wish to take any pride in Irish things, but rather should be urged and educated to take pride in Ulster things. Nevertheless, a growing number believe that this approach actually diminishes their Protestant heritage.

Witness the role and influence of radical Protestants in Ireland: Grattan's parliament; the Volunteer Movement; Ulster Tenants Right; Linenhall Library; Athens of the North; Young Ireland (led by sons of the Presbyterian manse); Armour of Ballymoney; William Orr of Farranslane; James Orr of Ballycarry; Samuel Neilson of Belfast; Molly Ward's Tavern; May Ann McCracken and the Charitable Institute; Volunteers' Guard of Honour at the opening of the first Catholic Chapel in Belfast; industrial Ulster was built by radical Protestants (not by right wing sectarian demagogues); birth of historic Republicanism; the Irish language, music, and design was all kept alive by Protestant poets, musicians, and artists.

Of course, when we refer to 'Protestants,' we have to be mindful that, for many, an acceptance of this label has more to do with all the ingredients which make up their identity, not necessarily the practice of religion - and the dwindling attendance at many Protestant churches is testimony to that. Nevertheless, for a significant number of 'Protestants,' the religious component of 
their identity is the fundamental one. Some insist that the continuing conflict between Protestantism and Catholicism in Ireland is historically inevitable:

The Pope is still the anti-Christ and all Protestants should be made aware of this. No apology is offered for this statement - it is backed up by biblical truth. The guiding hand of Rome is still with us. The Roman Catholic church supported the 1641 Protestant holocaust and gives it support to the slaughter of today - how many terrorists has it excommunicated? We have every reason to fear the Church of Rome, for if they had their way, we would be back in the Dark Ages.

However, many 'religious' Protestants feel that to portray Protestantism in such stark 'conflict' terms only serves to reinforce its image of being antiCatholic, rather than non-Catholic. Protestantism, they feel, must be viewed in a much broader perspective.

The term 'Protestant' stems from the Latin 'Protestant' and 'testari' which means 'to bear witness.' It is not, therefore, a negative protest but a positive one. Protestantism is not necessarily anti-Catholic. Presbyterianism has protested against Anglican oppression; Congregationalism has protested against Presbyterian theocracy; non-subscribing Presbyterians have protested against Confessional Presbyterians. The process of socio-religious evolution has constantly defined and redefined the nature of Protestantism and, particularly in Ulster, it came to stand for religious and political dissent.

Others feel that the Northern Ireland conflict has tended to reduce their religion to a narrow stereotype, shown of its rich diversity.

I believe that there are certain important elements within our Protestant tradition which have been forgotten by many people. I grew up with a pride in the emphasis upon the right of private judgement, of the basic equality between all people, and a respect for truth, even when it might be considered inconvenient. My sense of being Protestant was not related to being part of any ascendancy. I feel that pettiness and sectarianism has undermined our Protestant heritage, as well as certain attitudes displayed by Protestant leaders towards Catholics. For example, for Protestants to profess a commitment to 'civil and religious liberty for all,' and then attempt to deny civil rights to others, as was done in 1969, is hypocritical. For me, the real Protestant tradition is open, tolerant, and accommodating.

Perhaps, the Civil Rights issue highlights the complexity of the matter. When 'Protestant' leaders opposed the Civil Rights marches, was it simply their Protestantism they felt was under threat, or the political system in which Protestants had invested all the diverse components that went to make up their heritage, in particular their sense of 'Britishness?'

Many simplistic notions abound as to what it means for Ulster Protestants to feel 'British,' some often amusing: 
Many years ago, I walked into a bookies to find two mates of mine arguing about whether Australia was or was not a British Dominion, and when I confirmed it was, one says to the other: 'I told you we owned Australia.' And him with the backside hanging out of his trousers, who must have 'owned' next to nothing!

Most working-class Protestants, however, would readily accept that being 'British' did not necessarily mean 'material' advantage - far from it - it was more the sense of pride they gained by being part of all those things which comprised 'Britishness' - democratic ideals, the great institutions, the culture, the English language, the world-wide renown and prestige, the Empire, the monarchy. Many of these components, from the perspective of today's world, might now be somewhat tarnished, but the idea of a 'British way of life' is still a positive concept to many people, whatever its critics might say. For Ulster's Protestants in particular, all of these aspects of 'Britishness' are very real to them, and the cause of much pride. If one complements that with the numerous population movements between the two islands throughout our history, then the consolidation of a close relationship with mainland Britain would, in any 'normal' circumstances, only seem perfectly natural.

Indeed, some claim, with a deliberate irony, that the problem does not really lie with Ulster's Protestants trying to convince themselves that they possess a British heritage, but with the rest of Ireland trying to pretend that they do not.

What's so wrong with being a part of 'British' history? Republicans continually harp on about 800 years of oppression, and if they want to remain fixated on that, that's up to them. But name me a world power that hasn't been guilty of oppression at one time or another. It hasn't all been negative. Whether Irish nationalists like it or not, the richness of Ireland's heritage owes plenty to its 'British' connections, from the arrival of Saint Patrick to the contribution made to Irish literature by the great Anglo-Irish writers. Look, the day after Nelson Mandela became president of South Africa he announced he was re-applying for admission to the British Commonwealth. Now his people knew full well what it was like to suffer at the hands of white Europeans, Brits included, yet he still saw something valuable in renewing links with this unique 'British' family of peoples. People claim Ulster Protestants are narrow-minded. I think Irish nationalists are equally so. It is time they grew out of their hatred of everything 'British' and acknowledged all the positive things.

Even if Irish Republicans do not care to acknowledge these 'hidden' aspects of their own heritage, Protestants feel it is high time Republicans at least began to acknowledge something which is only too visible to everyone else:

Sooner or later the Republican movement has to accept that the real 'British presence' in Ireland is not the few thousand British soldiers here, but the one 
million Protestants - and God knows how many Catholics - who feel they have a 'British' heritage.

However, the 'bedrock' of the heritage of Ulster Protestants is their deeply-held belief that they 'belong' here. They are as attached to their corner of the world as any people anywhere. Irish Nationalists often try to portray them as 'interlopers' who came over with the Plantation, the implication being that this Plantation occurred only 'yesterday.' Few would make such a claim against present-day Americans, and yet only two years separate the Plantation of Ulster and the first permanent British settlement in North America (Jamestown, Virginia). Nevertheless, such perceptions of Irish history remain a potent factor within the communal consciousness of today - whether Cromwell's massacre of Catholics, or the 1641 massacre of Protestants. Some now feel that a stop must be made to this 'history roundabout' and a thorough reassessment begun.

It's time we began to look more honestly at where we have come from and where we are going. It's time we looked anew at Irish culture, British culture, Orangeism ... all of it ... everything. Without trying to belittle any of it. Let's look at it with today's needs in mind, not with a vengeful eye on the past. Prods have to get away from this notion that if you question anything you're being disloyal. That's nonsense.

While many Protestants might have some difficulty articulating the ingredients which make up their sense of 'belonging to Ulster', few observers could doubt its reality, particularly as exhibited by the working class.

A prominent Unionist political recently said - in private conversation - that, in the event of a United Ireland, he would simply leave. But we can't just up and leave, that's not an option for ordinary people. And anyway, we wouldn't want to - this is our country and nobody's gonna move us!

A somewhat narrower sense of 'belonging' within the Protestant working class is also evident in territorial rivalries - Upper Shankill v. Lower Shankill; Sandy Row v. The 'Pass;' West Belfast v. East Belfast; urban v. rural ... Family networks and community allegiances play an important part in Protestant working-class life, and the dismantling of old communities and the subsequent move to suburban estates has often compounded the demoralisation brought on by the Troubles.

\section{THE WORKING-CLASS EXPERIENCE}

Although the Protestant working class is seen by many to be the mainstay of Ulster Loyalism, a fundamental component of its own self-identity is undoubt- 
edly the working-class experience. The cumulative legacy of working-class life through the generations has forged strong bonds within many local communities, supportive for many, claustrophobic perhaps for others. And while the 'work ethic' label often applied to the Protestant community is now being challenged, there is no doubt that, prior to the Troubles, people within the Protestant working class did work hard and believed it important to be industrious, for along with this came a sense of pride even amidst conditions of poverty.

The 'work ethic' label even had a cultural dimension, with the notion that the 'Planters' were an industrious stock of people who transformed the Ulster landscape, whereas the 'natives' were lazy. This had been translated in modern times into the perception that the Catholic community was quite content to live on welfare benefits while 'doing the double,' and that Catholic poverty was a reflection of their social and religious attitudes. One result of such perceptions was that a 'blind eye' could be turned towards genuine social injustices suffered by the Catholic community.

But what of the social injustices experienced by the Protestant working class? The reality of their daily lives left them little escape from the problems faced by working-class communities anywhere: poorer education, of having limited control over circumstances, a lack of confidence, and a squandering of talent. And, Nationalist propaganda notwithstanding, this deprivation was little ameliorated by their allegiance to the ruling Unionist establishment.

Republicans have long promoted the notion that the Protestant community was much better off than the Catholic community. This 'half-myth' retained its potency because Protestants even believed it themselves. The reality was that whatever privileges the Protestant working class was 'granted' were merely 'crumbs from the table' - it simply suited certain people to tell us that these 'crumbs' had to be held on to at all costs.

In the past, the dilemma for the Protestant working class was that to highlight social inequalities carried political risk. It was believed that any criticism of government policies would be detrimental to the Northern Ireland state and simply play into the hands of Republicans. The Unionist establishment expertly avoided any need to tackle inequality by playing on this fear. That social inequalities were nevertheless very real to ordinary Protestants is revealed by how few now shed tears for the old Stormont.

There was a terrible feeling of betrayal when Stormont was swept aside, but now that it has gone it is time working-class Prods admitted that, other than the mistaken notion that it was somehow defending our 'interests,' we got precious little from it - our lives were hardly a bed of roses. If a devolved administration ever returns we must make it perfectly clear that we don't want one like the old one - that would be totally unacceptable.

The present Troubles have released many dormant frustrations: 
Our Unionist politicians and church leaders never showed the slightest concern for the 'benefit rights' of ordinary Prods. Even at the beginning of the 'Troubles,' the only ones offering welfare advice to working-class people were a few Catholic priests - and I know, because I had to go to one of them.

While in Great Britain such social needs might have resulted in a sizeable 'labour' vote, in Northern Ireland the stance taken by the British Labour Party to a United Ireland has seriously undermined whatever appeal a labour party might have among working-class Protestants. Despite the existence of independent labour candidates, the mood at present is still largely to support the main Unionist parties - but not as unconditionally as before.

All a Unionist candidate had to do was appear at a street-corner, wave the Union Jack, shout 'This we will maintain', and he was as good as elected. Those days have to be brought to an end. It's time we called our politicians to account for failing to address our real needs.

Although many voices within the Protestant working class are becoming increasingly vociferous in such demands, the task facing them is immense. For the Protestant working class has been demoralised on two fronts simultaneously. The Troubles - which forced Protestants into cultural and political 'retreat' - have coincided with the massive erosion of the industrial base which had provided them with their economic security. ${ }^{7}$ Put simply, many of the Protestant working class are no longer 'working' class.

The demoralisation this has engendered is very real, for much communal and individual 'worth' accrued to industrial skills, even to the detriment of other avenues of advancement. Further education, for example, was seen as a second-best option to getting into a trade, and attitudes to education are still highly ambivalent. In the past, children who could have gone on to secondary education often did not do so simply because their parents could not afford the uniform; nowadays, the same talented children miss out on higher education opportunities as much because the social conditioning of their parents' attitudes has prevented such opportunities being viewed positively. The current scarcity of job opportunities, coupled with the poor achievement record of many schools in Protestant working-class areas, means that working-class youth are badly losing out on both fronts. ${ }^{8}$

The loss of a working-class identity is the 'hidden' component of the present crisis, and inevitably has a bearing on political perceptions.

The IRA have been targeting economic targets here for years, but they haven't done as good a job as Thatcher and her cronies did across the water. Where is Britain's industrial might now, which we are all so proud to be a 
part of? We know that the British don't care tuppence for us, but sure they don't even care about their own people - half of England has become an industrial wasteland. When I watch the Tories on the box, I ask myself - do I really want to be loyal to yon crowd?

The opinion of many within the Protestant working class is that the adverse socio-economic circumstances confronting them have been ignored by everyone (except when it suits - the Protestant middle class, the media, the government, the politicians). The remarkable growth of community organisations over the past twenty-five years is a sign that ordinary people realise they have to confront their social and economic circumstances themselves. Nevertheless, the balance of power is heavily weighed against them. And although the decision-making processes are remote from working-class hands, Catholic as much as Protestant, present antagonisms blur such a realisation:

We get nothing for our areas, all the bloody grants to the Catholics. One moan from them and they get whatever they want!

Community workers see the inherent dangers in such a perception.

We need to stop comparing the two working-class communities in this way. Perhaps rather than talk of either side being preferentially discriminated against, we should talk of both communities being equally disadvantaged as working class. Take the 'equal opportunities' issue. I accept that to allocate jobs on the basis of religion is wrong, but I would imagine that there are far more job opportunities denied to ordinary working-class people simply because their home address contains the word 'Shankill' or 'Falls.' To concentrate on religious or sex discrimination is to ignore another, far more fundamental inequality.

There is no doubt that the political situation and the economic downturn are combining to reinforce the demoralisation and lack of self-esteem that is growing daily within the Protestant working class, and augurs ill for the future.

\section{THE IMPACT OF THE 'TROUBLES'}

The Troubles have had a profound impact upon both working classes, not the least because the death and destruction which has ensued has disproportionately affected their communities. Within the Protestant community, opinion about the root causes is still mixed:

The biggest mistake the Prods made was not to join in the Civil Rights marches. And even though we didn't, we shouldn't have tried to justify malpractices. We must accept that we were more than aware of the abuses 
of power which went on in the past; they might not have been done by us, but they were supposedly done for us, and we were only too prepared to keep quiet about them. It was inevitable that some sort of crisis would erupt whether we like to admit it or not, Northern Ireland was a sick society.

Others remain far more cynical:

People imagine that Civil Rights was all about reform. Nobody should be fooled by that. Nationalists and Republicans don't want to reform Northern Ireland, they want to destroy it! We could be the most progressive state in the world and the IRA would still be trying to bomb us out of existence.

Even those who accept that there were legitimate grievances feel deeply embittered at how the situation progressed:

Okay, we stupidly fought the Civil Rights people every inch of the way, but their demands were eventually all met - they got everything they asked for. ${ }^{9}$ If Catholics had been prepared to take one step at a time, we would have had to reach some accommodation with them, but no, nothing was ever good enough, and their insatiable demands and the 'all or nothing' of the IRA has just bred a deep resentment and anger.

There is now widespread cynicism about Nationalist and Republican motivations:

It's a bloody laugh to suggest Republicans ever gave a damn about civil rights! They followed a policy of non-participation then accused the state of not including them. They always asked for more than could be given, then accused the state of discriminating against them. They used their 'nationality' as a reason to murder but accused the state of being bigoted and sectarian. They spread half-truths all over the world about the state they profess to hate, while willingly accepting all its monetary benefits. Despite claiming to be fighting for 'democracy,' all their gains have been made by using bombs, guns, murder, and terror - not by any sound political policies. But it has all been counter-productive. For I'll tell you what they have done - in their obsession with destroying a single 'geographical' border, the IRA have succeeded in creating a thousand more borders in the minds of our people.

However, whatever the differing perceptions about the Civil Rights question, twenty-five years on they seemingly bear little relation to the motivations of today. 
We have a whole new generation queuing up to join the paramilitaries. They haven't a notion how it all started, and most of them couldn't care less. Civil Rights is ancient history to them. They just see a hated enemy out to destroy them and they want to fight back. I agree with them - whatever those wrongs were, they don't justify all the IRA killings.

The legacy of over 3,000 deaths has also added its own stark reality to our two communities, which, for those who have suffered, transcends whatever history had gone before.

My father was murdered twenty-four years ago by the IRA. He was not a member of the security forces, nor did he work for them, nor was he in any paramilitary organisation. He was a labourer at the coal quay, whose only concern was to support his family - a wife, four children, and a baby on the way. He was an 'ordinary Protestant,' presumably one of those 'ordinary Protestants' Gerry Adams tells us have nothing to fear. Yet, the IRA left him bleeding to death in the street. In destroying our family, Sinn Fein/IRA taught me all I need to know about their 'peace process.'

When, at the beginning of the Troubles, the Protestant working class felt the full weight of British army heavy-handedness, few in the Protestant establishment wanted to acknowledge what was happening. It was only those at the receiving end, especially those sent to prison, who began, for the first time, to experience the British Army the same way Republicans had always done. Yet, the testimony of these Loyalists was frequently ignored or played down by Unionist politicians:

The army grabbed me one day and split my head wide open. They left me lying at the side of the road - probably thought I was dead. Yet when I tried to get our local politicians to hold a press conference, they squirmed away from such an idea - it would only help Republican propaganda, they said.

The Troubles have also profoundly affected the relationship between the Protestant working class and the police. Admittedly, the fact that Protestants once felt that the police were 'their' police was just the reverse side of the coin by which the Catholic community felt they were definitely not theirs. However, in their efforts to become more 'professional' and 'acceptable' to the two communities, the police have, in reality, become ever more distant from both working classes. The police increasingly live in their own enclaves away from working-class areas, and often view working-class citizens as (in their own words) 'peasants' or 'them.' One aspect of this is the increased harassment 
displayed towards working-class youth with the resultant diminution in community respect.

Some negative aspects of the past 25 years are a consequence of international trends rather than anything uniquely local - the increase in vandalism, youth alienation, drug abuse, family breakdown, and sexual abuse, as well as the decrease in respect shown to the elderly. While it is possible that some of these things may formerly have been largely hidden, there nevertheless remains the strong conviction that the Troubles have accelerated the process through which positive community values have greatly suffered.

\section{THE PROBLEM OF SECTARIANISM}

Sectariansim is the single most destructive element associated with the Protestant community, not only because of the damage it does to the image of that community in the eyes of outsiders, but because of the more insidious damage it causes within. Yet, while many Protestants undoubtedly harbour sectarian feelings, some of them extremely bitter, there is a growing number who acknowledge that such feelings are unacceptable.

Sectarianism, in its most innocuous dictionary meaning, simply denotes 'adherence to a particular sect.' The Protestant emphasis on individual choice has amply manifested itself in Northern Ireland, with a plethora of competing 'sects' and churches. Even in the Greater Shankill area there are twenty-three different denominations.

Is it any wonder that Prods cannot speak with one voice? I tried to get the churches on the Shankill to co-operate on a community festival, and gave up in frustration. There were too many personalities, too many competing interests, and I was left feeling they really had no heart in working together.

Even in class terms, Protestant churches can be discriminating:

Many of the mission halls and small churches sprang up to answer the needs of ordinary people - those who hadn't the 'proper' clothes, or who lacked the 'proper' social graces to be welcomed into the big Protestant churches, dominated by middle-class attitudes. The fact that so many missions were able to build their own churches shows that there is considerable talent in our midst.

The nature of Fundamentalist Protestantism has not only made it difficult to forge a sense of inclusiveness within the Protestant community, but prohibited any real link with the Catholic community, even on non-religious issues. And more significantly, Protestant assertiveness has often been translated into aggressiveness, with Catholics and Catholicism its target, and sectarianism in its more sinister dictionary meaning - its vehicle. 
The sectarianism inherent in the Northern Ireland state was highlighted world-wide when the Troubles erupted, and because working-class Protestants so vociferously opposed the Civil Rights cause, they were seen by most outsiders as willing accomplices in the state's sectarianism. Some now feel that it is time to challenge such an assumption.

Okay, we turned a blind eye to what was going on, we can't deny that. But what was going on wasn't within our control, the working class never had much power within the Unionist Party, nor were they ever encouraged to have any. It was men supposedly far more educated than us who created sectarian institutions. Why should we take all the blame? The Catholic community must realise that we would have had as much difficulty challenging the system as they would have had. And those con-men are still at it ... a top Unionist politician recently said that ordinary people shouldn't be getting involved in politics - politics should be left in 'their' hands. In their hands! After the bloody mess they've made!

Because of the 'mess' that was made - by whoever made it - the Protestant community, forced onto the defensive by the IRA onslaught, witnessed the rapid growth of paramilitary organisations, some members of which have been involved in an ongoing programme of retribution against the Catholic community. So horrendous have been some of their killings that commentators often portray the perpetrators as psychopaths, warped individuals unrepresentative of anyone but themselves. However, even those in the Protestant working class who abhor the killings acknowledge that such an interpretation would be grossly misleading.

We mustn't try to pretend that Loyalist paramilitaries are people who just dropped from the sky ... somehow quite different from the rest of us. They are part and parcel of our community - just as Republican paramilitaries are part and parcel of the Catholic community. Many are ordinary young men who feel they have been left with no choice but to fight back - the same young men who generations ago would have gone to their deaths in the trenches and been hailed as heroes. It's no use demonising them - we need to understand the circumstances which created them.

Those circumstances, in the eyes of the Protestant working class, included not only the relentless IRA violence but the unpalatable realisation that this violence was actually reaping rewards. As government repeatedly retreated in the face of IRA pressure, the Protestant paramilitary organisations took the view that 'if terror can work for them, it can work for us'.

No matter how much we might detest the nature of Loyalist killings, we cannot escape the fact that without the constant threat of Loyalist violence, 
we'd have been sold out long ago. We now know that during the ceasefire of ' 72 , the IRA were secretly promised more than was publicly admitted. Loyalist paramilitary leaders got a message to government to say that, if the democratic wishes of the majority community were ignored, then not only would Loyalist paramilitaries strike back in 'predictable' ways but also in completely 'unpredictable' ways. I believe that it was this threat which prevented the British government from selling us out back then.

In the present state of crisis confronting the Protestant community, an increasing number of ordinary people are prepared to tolerate Loyalist paramilitary actions, as much out of a sense of desperation.

Who else is defending the Protestant community? The Unionists would have caved in a long time ago, the police will feed at the hand of whoever pays them - but the Loyalist paramilitaries will never allow us to be sold down the river.

Nevertheless, many others believe that, by the very methods they use in their 'defence,' Ulster's Protestants are hastening the day of complete isolation. And even more importantly, these 'methods' are felt to be utterly immoral.

It's just evil, pure evil. Don't let's pretend there's any other word for it. These people have no right to take human life. No excuse can ever justify all this killing - and I mean on both sides. And it's not just the bereaved families who are suffering - it's all of us. The violence is slowly destroying our communities from within - the behaviour of the young people around here terrifies me more than any Catholics ever could.

Many Protestants believe that the most insidious aspect of the propaganda battle which the IRA has been allowed to win is the notion that their armed struggle is strictly non-sectarian.

It's time everyone was honest about this. The IRA have carried out plenty of purely sectarian killings, including some blatantly sectarian pub bombings, not to mention deliberately picking 'Protestant' towns for their biggest bombs, or targeting our housing estates. We're sick of their hypocrisy. The rest of the world might be fooled, but we're not.

Some go further and claim that not only has the IRA campaign taken on the attributes of sectarianism, but it was always inherently anti-Protestant:

To say that the conflict in Northern Ireland is not a religious one is an insult to the Protestant people who have been butchered for their religious beliefs for centuries. The 'ethnic cleansing' the IRA has been carrying out all along 
the border region is part and parcel of the same age-old anti-Protestantism. Outsiders imagine the IRA is fighting a 'modern' war - not a bit of it, this is just the 1641 massacres all over again.

Whatever its motivation, IRA violence is seen by many Protestants as a primary cause of their own sectarianism.

Before the Troubles I can honestly say that I felt no animosity towards Catholics. Live and let live. But over the years as I've watched families suffer-including my own - all I've felt is bitterness. With each IRA atrocity, I just feel more and more hatred towards the entire Catholic community.

Certainly the IRA is viewed as more than adept at manipulating this sectarianism to suit its own purposes.

The IRA are quite happy if Prods are sectarian - it fits their propaganda perfectly. They prefer the world to see Prods as bigots and them as defenders of oppressed Catholics. And when someone on our side takes a risk and tries to reach out to the other community - like Ray Smallwoods ${ }^{10}$ when he met with those Catholic priests - the IRA step in to prevent it. The IRA will make sure that Prods like Ray who are prepared to sit down with ordinary Catholics never get a chance to do so. They're afraid Catholics might get the 'wrong' impression!

Working-class Protestants also resent middle-class Protestants who point the finger at them when the charge of sectarianism is levelled at the Protestant community.

Many of these so-called 'moderates' are bloody hypocrites! They pretend not to be bigoted in case it affects their careers, but they're as bad as the next. Probably even more than working-class Prods, for people round here are not all as bigoted as everyone makes out. You take the response of ordinary people to the Shankill bombing. Okay there was real anger, and some talked of revenge, but there were just as many who realised - and said so out loud - that both communities were suffering, and that we all had to find a different way forward.

It was generally accepted that the question of 'sectarianism' had to be honestly confronted and while there should be an open acknowledgement that Protestants have been guilty of sectarianism, a deeper assessment had to be made of the circumstances which have led to this, for it is not unique to either 'side.' Indeed, recent contacts with members of the Catholic community have revealed that a growing sense of triumphalism, imbued with sectarian feeling, is manifesting itself within that community. 
The label of 'sectarianism' has also had a profoundly negative effect within the Protestant working class, for many ordinary Protestants feel increasingly demoralised not only by the criticisms levelled at them by outsiders, but by the actions of Protestants which serve to confirm such criticisms. Yet, while admitting that such actions reinforce the negative label, they believe it is totally unfair for the whole of the Protestant working class to be demonised as bigots.

Only when sectarianism is brought to the surface and fully analysed can there be any hope of eradicating it. The entire Protestant working class must define what it is as a community, good aspects and bad. Only then can more positive labels begin to gain any credibility.

\section{WHAT OF THE FUTURE?}

Some of those involved in community work over the years now believe that a concentration on localised socio-economic issues is manifestly inadequate the entire Protestant working class is facing a crisis which must be addressed in its totality. That community is now felt to be in 'retreat' on many 'fronts' simultaneously - economically, politically, culturally, even psychologically.

On the economic front, the Protestant working-class has suffered greatly from the effects of recession. That this recession is unrelated to the Troubles hardly matters anymore - for the narrow-minded it has become just another element for which a scapegoat must be found. For community activists, it is just another brick in a wall that seems to be insurmountable.

On the political front, the Protestant working class feels increasingly isolated by its enemies and betrayed by its friends. All shades of nationalist opinion have now openly joined forces to either coerce or gradually pry the Protestant community away from its 'Britishness.' And the 'British' on the mainland never really cared that much anyway.

If the British government really believed we were an integral part of the UK do you think it would have allowed its citizens to have suffered this state of terror for so long. Can you imagine it being tolerated anywhere in England - not a chance! And tell me any other part of the UK where the British government would meekly accept that flying the Union Jack - the national flag, after all - can be considered offensive!

Working-class Protestants watch in bewilderment the response of government and media to each successive nuance in the politics of Sinn Fein, including the current 'Hume-Adams Peace Process.'

How come everyone has fallen for all this crap - any fool can see that their 'peace process' is merely a new tactic, a 'piece by piece' process. The IRA don't want peace - they want victory and surrender. 
This gulf in perception between Loyalists and Republicans is not one-sided. In the opinion of Protestant community workers the Republican movement is still, despite twenty-five years of opportunity, depressingly incapable of anything more than a stereotypical understanding of the Protestant working class. A former Republican prisoner recently dismissed a Channel 4 documentary on the Shankill community by saying to its producer: 'That wasn't the real Shankill. The 'Butchers' ... that's the real Shankill.'

The Republican movement have done absolutely nothing to reach out to the Protestant working class, absolutely nothing. They're fixated with the 'Brits' - they've a desperate need to talk to them ... but not to us, they avoid us like the plague. They probably realise they can't fool us the way they do everyone else - we can see right through their phony rhetoric, see them for what they really are.

Most Protestants do not believe that Republicans have any real desire to engage their community in genuine dialogue.

They've made it perfectly clear they have no time for us. When a leading Sinn Fein spokesman was asked his opinion of the policies of the workingclass Progressive Unionist Party, he retorted: 'Progressive' Unionists? You might as well talk of 'progressive' Fascists!

Some of the current Sinn Fein demands only meet with derision among Protestants:

It's pathetic the way Republicans are demanding that the British should become 'persuaders' in getting the Prods into a United Ireland. Can you believe it! They need the hated 'Brits' to do it because they know they haven't a 'snowball's chance in hell' of doin' it themselves! Why don't Republicans come out and admit that it's not the Prods who have a 'problem' with their identity, it's the Republican movement who have the problem they just cannot accept that one million people living on this island genuinely consider themselves British!

To the Protestant working class, the Republican movement's present position of being in the ascendant has not been accompanied by any preparedness to be generous and accommodating - which has often been the case in other conflict areas around the world - but has simply reinforced the Nationalist community's triumphalism and latent sectarianism. Given such perceptions, whether accurate or not, any talk of accommodation raises deep fears.

Are Ulster's enemies seeking accommodation with us? Are Nationalists or Republicans asking to sit down with the Protestant community and address 
their fears? Not a bit of it. This kind of thinking only increases the demoralisation of the Protestant community. We have been betrayed by our government and walked upon by our politicians, and now we are being demoralised by this type of thinking, for it doesn't get us anywhere. Whatever you come up with, the Nationalist community will reject it as not enough - so you just help destroy whatever confidence remains within the Protestant community.

Ironically, a growing number feel that the only way now to protect the Protestant community is to end its reliance on the 'Union' and look to themselves - an Ulster Protestant version of Sinn Fein:

Our enemies have never had any interest in us - it is time we began thinking of ourselves first. Give the government notice that they either accept and embrace Ulster's loyalty or get out and leave us alone to determine our own future.

The voices who would 'go it alone' fall into two camps: those who call for an Independent Ulster, the structure of which they acknowledge would be little more than a 'Protestant homeland,' and those who would wish to create a completely new society to which both communities could give allegiance. The former believe that the latter are out of touch with reality:

You cannot reconcile the irreconcilable. For even if there weren't different loyalties, after twenty-five years of killing there's no way that our two communities could ever trust each other again. When all these do-gooders and clergy harp on about compromise and accommodation, let them spell out exactly what it is they expect us all to agree to. I think you'll find that, aside from fine-sounding words, there'll be precious little even they will be prepared to compromise on. It's time we accepted that we have little or nothing in common.

Those who believe in a 'new' Ulster, however, respond that both communities have gone through so much together, and become so estranged from their respective 'friends' in London and Dublin, that they have enough in common to make it work.

I think all this talk of a 'Protestant homeland' is essentially defeatist. Rather than 'protect' the Protestant community I think such an eventuality would actually endanger it. I often wonder whether people who talk of an Independent Ulster see it as the 'best option' or the 'last resort.' To me, the only effective way to 'save' Ulster - or even the Union - is to change it for the better, and make it an attractive proposition for both communities. Let's 
be honest, Britain doesn't want us, and Dublin would panic if they thought reunification was just around the corner.

While some within the Protestant working class desperately hope for a sign that the gun could be taken out of politics and real dialogue allowed to emerge - no matter how painful - they despair that such a scenario plays any part in the consciousness of the Republican movement:

The Protestant community has little left to give up-except its identity. And it looks increasingly that that's exactly what the Nationalist community are waiting for, that's all that will satisfy them.

On the cultural front, attitudes are equally diverse. Many want to 'close ranks' as if somehow the rekindling of a 'pure' identity will provide some semblance of communal security:

We should declare ourselves 'proud to be Prod,' and cease all this flirting with 'Irishness.' The Ulster people have nothing to do with the Irish, and I cringe every time I hear a Prod say that the Gaelic language is ours as well. It has nothing to do with us!

However, others feel that such voices are simply adding their number to those English chauvinists and Irish nationalists who, for so long, have denied the Protestant community their rightful heritage.

We must reclaim our real heritage, and if we find it is also an 'Irish' heritage, we must have the courage to say so, just as we would hope the Catholic community would have the courage to admit to the 'British' part of their heritage. From some of the material coming out recently, it is quite evident that both communities have long had a 'shared' heritage. Why can't we build on that one?

What is the balance sheet of all the conflicting needs, fears, and aspirations held by the Protestant working class? Readers hoping for a definitive answer to that question will be disappointed, for it is evident that the Protestant working class contains a great diversity of opinion, a diversity that might surprise even its detractors. Indeed, the very existence of such a diversity of opinion within the Protestant community is itself an answer to all those media commentators who previously judged the Protestant working class to be a monolithic mass, reactionary in outlook, and incapable of serious reflection.

While most Protestants, often with good reason, believe that the 'outside world' is fundamentally hostile to their cause and only too willing to portray their community on the basis of worn-out stereotypes - after all, every good 
drama needs its 'baddies' - many now readily admit that their negative image is as much their own fault. Over the years, there has been a marked inability by their political leaders to adequately present the Unionist 'case,' coupled with the defensive and aggressive attitude the Protestant working class has displayed towards the media.

It's still goin' on. I was up the Shankill the other day and this wee woman was shoutin' at a crew filming what was left of Frizzell's. I calmed her down and said 'Look love, we shouldn't have been chasin' these people all these years, we should have been invitin' them in!'

All that can be said with any certainty is that an energetic reassessment is presently underway within the Protestant working class, except of course among those already so demoralised that they have ceased doubting their eventual fate. Much of that energy is being channelled into plans for resistance, and no-one should be under the misapprehension that the Protestant working class will permit itself to be docilely led into an unacceptable future. But others are directing their energies into a radical reappraisal of where they have come from and where they are going.

Before the Troubles we were 'confidently dependent.' It is now time to grow up to adulthood. We must challenge all we took for granted, just as we ask the Catholic community to challenge its own 'certainties.' Both communities must put the Plantation and 1641 behind them for ever. We must face the realities of the present, assess all our relationships, and build for the future. The Protestant community must also confront its highly sectarian image - we are not seeking exoneration, but explanation.

There is also widespread admission of the wrong both communities have done each other:

Protestant and Catholic suffering is equally heart-breaking. There are no innocent parties to the Northern Ireland conflict. To claim innocence is to be hypocritical - and Loyalists and Republicans have been hypocritical enough.

There are even those voices - few in number, no doubt - who dare to pose previously unthinkable questions:

I feel that the real threat to our continued existence as a people comes not from Republicanism but from our own insecurity and resistance to change. For too long, we have linked our survival as a people to Britain, the Union, Orangeism ... But if, at the end of the day, these things fail us, does that mean we are finished as a people? Surely the Protestant people of Ulster have more character, are made of stronger mettle than that? We must look to the future 
and carve out a new role for ourselves. We must create a new vision. If we collapse like lost children once 'mother' England lets go our hand, then all the claims made by Irish nationalists that we never possessed a 'real' identity to start with will only have been proven correct.

Members of the Protestant working class are neither all irredeemable bigots nor dormant progressives. Perhaps, in their diversity, once seen as their greatest weakness, lies their greatest strength, for it will be the preparedness to look at a diversity of options which could enable both communities to move forward into the future. Ironically, both those within the Protestant working class who are preparing to 'resist' any further surrender, and those who wish to create a new vision for the future, voice an identical perception:

Whatever happens we will take responsibility for our own destiny.

\section{IRA CEASEFIRE POSTSCRIPT}

Although the media, in its inimitable fashion, had been hyping up the likelihood of an IRA ceasefire for some time - ably abetted by leaks from Republican sources - the Protestant working class was as ill-prepared for the announcement, when it came, as any other section of the population. To many ordinary Protestants, the ceasefire engendered deep suspicion, for there was genuine disbelief that the IRA would have relinquished its 'armed struggle' without having received assurances that its ultimate goal of a United Ireland was to be made reality by other means. And yet, as with the rest of the population, most ordinary Protestants genuinely wanted to believe that real peace was now possible.

A poll carried out for the Shankill People five days after the ceasefire announcement highlighted this seemingly contradictory mixture of hope, suspicion, and pessimism. 'Hope' was indicated by the $72 \%$ of those questioned who welcomed the IRA's announcement. 'Suspicion' was indicated by the 55\% who felt the British government had 'sold out' to the IRA. And 'pessimism' was indicated by the $70 \%$ who felt the ceasefire would not last, although $61 \%$ desired that Loyalist paramilitaries should nevertheless call their own ceasefire.

This juxtaposition of hopes and fears should not come as any great surprise, for ordinary people on the Shankill Road have had their emotions buffeted for twenty-five years and their trust and hope repeatedly betrayed. Yet despite this, perhaps what might surprise outside commentators is not only the overwhelming desire for peace the survey revealed, but the willingness among the residents of the Shankill for their own community to respond in a positive fashion.

The ceasefire has highlighted the full range of emotions and perceptions contained with the Protestant working class. One such perception is that it is 
almost too soon, not only to assess whether there is now a genuine opportunity for peace, but to act upon that opportunity in the immediate term.

Both communities need space to grieve. There is so much hurt and pain around that for some it will be many years before they can come to terms with their personal loss, if ever. Others might be willing to begin to work towards some accommodation now, but people must realise that twenty-five years of suffering cannot be brushed aside just like that. Time will be needed for wounds to heal. Indeed, some feel that their own personal wounds are too deep to ever heal:

Right at the beginning of the Troubles my family had to endure unbelieveable harassment because we owned a number of shops in Catholic areas - a business my father had built up by hard graft. Republicans tried to drive us out by verbal and physical assaults - on my mother, my brother, and on myself - I still bear the scars to this day. Finally, when that didn't work they brutally attacked my father, and our family had to sit agonising for two weeks by his hospital bedside before he died. Not only were we all completely devastated, but I was robbed of my teenage years, and it is only recently that I have been coming to terms with what I have lost. Yet, when I was interviewed the other day by the media - just after the ceasefire - and said that I was still filled with hatred, they told me: 'Oh, we couldn't use that.' So it seems I am not even allowed to give voice to the reality of what the IRA has done to me, in case it upsets those who now desire to parade apologies for gunmen as 'peace-makers.' It makes me sick.

To those who have been the direct victims of IRA violence, recent postceasefire appeals by leading Republican spokesmen to their 'Protestant brothers and sisters' have been received not just with astonishment, but deep anger.

Who do they think they are - or more to the point, who do they think we are! Just because it now suits their new image, as they parade their cause on the world stage, to talk of us as their 'brothers,' we're supposed to forget that, before the ceasefire, they spoke of us with utter contempt. And Adams had the cheek to say of Michael Mates: 'if this man is genuinely seeking consent, why isn't he out there seeking consent, negotiating consent?' I haven't seen much of Adams and company 'out there seeking consent' over the past twenty-five years!

Many others whose families have not suffered directly at the hands of the IRA still harbour a deep distrust:

How can we believe that they have given up the gun when all their guns are not only still there, but are being moved to safer locations? I don't accept for one minute that this ceasefire is meant to be permanent. This is just the IRA's latest tactic. 
Others take a more pragmatic approach:

I don't think the IRA can ever say their ceasefire is 'permanent.' And even if they did, what difference would it make? All it would take would be for a breakaway group to disown the leadership and it could start up all over again. No, I don't believe it is permanent - but I do believe that, if both communities put the proper effort into it, we could make it permanent.

Some within the Protestant working class feel that, while the ceasefire has not necessarily created a totally new situation, it has nevertheless opened up new possibilities, which must not be thrown away.

Okay, let's accept that the IRA ceasefire is simply a new tactic. So what? Isn't it a much more acceptable tactic than killing? During any period that the Republicans take violence out of the equation, they can only move forward in three ways. By using political means - and this will include harnessing all their Irish and American supporters. Or by a return to street politics. Or by persuasion - though they haven't spent much time practising for that. Why should we fear any of these alternatives? We should feel strong enough in our own position to say: okay, we accept your challenge, we'll argue our case with you point by point. For I really believe that, in the end, we will win the argument.

Despite all the factors which have added to the demoralisation and isolation experienced by the Protestant working class over the last twenty-five years, there are signs that some sections within that community have grown in selfconfidence and found a new ability to articulate not only the needs of their own community, but their vision for the whole of Northern Ireland. They also feel that it is time the Protestant working class developed its own response to the present situation.

We can't afford to let our politicians destroy whatever opportunities might be created. Let's face it, many of our politicians must be frightened by the ceasefire. And it's not hard to see why - if our fears about being sold out are finally allayed, in a few years from now these politicians could be redundant. We must analyse the situation from our own needs, not theirs. We already know that those needs are not always the same. We've been marched up to the top of the hill and down again once too often.

Some take reassurance from the fact that, despite twenty-five years of terrorism, the 'British' people of Ulster still remain British and that - unless some secret deal has indeed been done, despite all the assurances - it is the IRA's 'armed struggle' which has had to confront harsh reality. 
Are the IRA any closer to their goal after all their efforts? No. Not only that, but they have shaken the political establishment in the South out of their old Republican shibboleths and forced every brand of constitutional nationalism to openly declare that consent, not violence, is now the only acceptable solution to the 'Irish question.' The IRA have scored a massive 'own-goal.' Their methods have finally led the rest of Ireland to view the 'physical force' tradition as a hindrance to this island's future.

If the ceasefire has indeed resulted from Sinn Fein and the IRA finally facing up to political reality, there is the belief among some Protestants that how their community responds will be of vital importance for the way the situation now develops.

Even though the IRA terror campaign has been defeated, not by the British Army or the RUC, but by the endurance of the ordinary people of Ulster, it is no time for triumphalism. The indefinite postponement of a United Ireland, aggravated by Protestant triumphalism, could quickly lead to massive disillusionment among ordinary Catholics. It is up to us to move the situation forward before that happens. We must show the Catholic community that even though they might feel betrayed, both communities are no longer 'back to square one.' Both communities have moved, for there is no denying that the Troubles have acted as a very painful catalyst.

While many Protestants are still intensely suspicious of the Catholic community, and just as many remain deeply embittered by all that has transpired during the past twenty-five years, others feel that the moment has arrived to transform the situation radically.

Both communities have suffered and both communities have caused that suffering. We cannot undo the past, but we can rebuild for the future. If Republicans are prepared to use democratic means to try and 'persuade' us to go into a United Ireland, well, let them go ahead and do that. Our task will be to 'persuade' Catholics that the Union is the best option for them. To be honest, I believe that if we really put our minds to it, it is we who would have the easier task. But it will mean Protestants having the courage to sit down with the Catholic community and change Ulster so that it reflects the identities of all its people. That will mean the Catholic community feeling able to give proper expression to its sense of Irishness alongside our sense of Britishness. I don't see why a new Northern Ireland could not incorporate both.

\section{OCTOBER 1994}

On 13 October 1994, a few days before this [essay was first published], the Combined Loyalist Military Command announced that all Loyalist paramili- 
tary organisations were declaring a ceasefire. The ceasefire statement, which called for all 'battles' in future to be solely 'political' ones, also said: 'Let us firmly resolve to respect our differing views of freedom, culture, and aspiration and never again permit our political circumstances to degenerate into bloody warfare.'

\section{ENDNOTES}

1 Life on the Interface, Island Pamphlets No 1.

2 For example: Beyond the Religious Divide, New Ulster Political Research Group, 1979; Common Sense, John McMichael, Ulster Defence Association, 1987; Sharing Responsibility in Northern Ireland, Policy Document, Progressive Unionist Party of Northem Ireland, 1991; The Ulster Volunteer Force: Its Negotiating History, dissertation by Roy Garland, 1994, copies of which are available in Belfast Central and Linen Hall Libraries.

3 Loyalist use of the term 'Ulster' to describe Northern Ireland is anathema to most Irish nationalists, who prefer to call this 'British invention' the 'Six Counties,' in recognition of the three remaining Ulster counties incorporated into the Republic of Ireland. Ironically, the 9county configuration staunch nationalists deem to be 'historic Ulster' - and which includes Donegal, Monaghan, and Cavan -is itself a 'British invention.' For even up to the Anglo-Irish and Gaelic lordships of the early 16th century, 'Ulster' contained territory presently in Co Louth rather than Co Cavan, and it was Queen Elizabeth's administrators who subsequently redefined the province's boundaries. See A New History of Ireland, ed. Moody, Martin and Byme, vol. IX: 'Maps, Genealogies, Lists', map 47, Oxford, 1984.

4 The quotes throughout this document come from three sources: opinions expressed during the main discussions; outside comments made to members of the discussion group and relayed back; and, finally, the various documents which were submitted to the group.

5 Parl. Deb. III, xv, 325; Piolot 13-i, 1834.

6 Radio broadcast, St Patrick's Day, 1935.

7 The workforce at Belfast Shipyard, for example, has plummeted from its peak of 42,000 to just 2,000; Mackies Engineering Foundry has dropped from 7,500 to 390. Many major outside companies with local plants have since departed Northem Ireland -I.C.I., Courtaulds, British Enkalon, G.E.C., Goodyear, Michelen. The collapse of the linen industry saw the closure of numerous mills. Decline or near demise has hit other major employing sectors - Gallaghers, the Ropeworks, the stevedores at the docks ... Small businesses in the Greater Shankill area, once numbering over 600 before redevelopment, now only total 127 .

8 In 1986/87 in the Greater Shankill area, only $4 \%$ of primary school children passed the '11 plus' examination, when the Northern Ireland average was $21 \%$. In 1987/88, the total of children in the Greater Shankill area who passed was 11; in 1988/89 it was 13. In 1992 37\% of secondary school children did not gain any GCSEs. In 1992 no secondary school pupils went on to Higher Education from Greater Shankill schools. (Further analysis of educational and social deprivation in the Shankill area is contained in the Greater Shankill Regeneration Strategy Consultation Report.)

9 On 30.08.88 the Irish News catalogued some of the Civil Rights gains:

The establishment of the Housing Executive ended for ever the disgraceful policy of discrimination which had fuelled the Dungannon march. The re-introduction of PR and the abolition of gerrymandering ensured a fair system of representation in all areas. The setting up of the Fair Employment Agency and recent steps to strengthen its powers have made discrimination a much more difficult process. And, largely as a result of the Civil Rights challenge, Stormont itself has gone for ever.

10 Formerprisoner who, through the Ulster Democratic Party, tried to move Loyalist paramilitaries away from the gun and towards the political approach. In July 1994, while engaged in negotiations with a wide spectrum of political opinion - including Catholic clergy - he was murdered by the IRA. 